\title{
Eksistensial Humanistik Dalam Perspektif Bimbingan Konseling Islam
}

\author{
Syatria Adymas Pranajaya ${ }^{1}$, Ananda Firdaus $^{2}$, Nurdin Nurdin ${ }^{3}$ \\ ${ }^{1}$ Institut Agama Islam Negeri Samarinda \\ ${ }^{2}$ Institut Agama Islam Negeri Samarinda \\ ${ }^{3}$ Universitas Mulawarman Samarinda
}

\begin{tabular}{l} 
Article Info \\
\hline Article history: \\
Received mart $12^{\text {th }}, 2020$ \\
Revised April $20^{\text {th }}, 2020$ \\
Accepted April $29^{\text {th }}, 2020$ \\
\hline
\end{tabular}

\section{Keyword:}

Eksistensial;

Humanistik;

Perspektif;

Konseling Islam

\begin{abstract}
Humanistic existentialism considers that humans have authority over themselves in determining actions, changes, and destinies. The method used is literature study with a qualitative approach.Humanistic existential there are 6 positive basic dimensions that exist in humans:(1) Capacity for self-awareness; (2) Freedom and responsibility; (3) Creating self-identity and creating meaningful relationships with others; (4) The search for meaning, purpose, values and targets; (5) Anxiety as a living condition; (6) Awareness of the coming of death and non-existence, in which the six dimensions will be associated with Islamic counseling. In Islam, there are values in the 6 basic dimensions of humanistic existential positivity such as the capacity for self-awareness that is about awareness of being a servant of God assigned as caliph on Earth, freedom of action but also being responsible for his actions, creating harmonious relationship with others, realizing that the self has limitations and must be willing to face death whose nature cannot be avoided as living creatures and others.
\end{abstract}

\begin{abstract}
ABSTRAK
Eksistensial humanistik menganggap bahwa manusia memiliki otoritas terhadap dirinya sendiri dalam menentukan tindakan, perubahan, serta nasib. Metode yang digunakan adalah studi pustaka dengan pendekatan kualitatif. Pada eksistensial humanistik terdapat 6 dimensi dasar positif yang ada pada manusia, yaitu: (1) Kapasitas akan kesadaran diri; (2) Kebebasan serta tanggung jawab; (3) Menciptakan identitas dirinya dan menciptakan hubungan yang bermakna dengan orang lain; (4) Usaha pencarian makna, tujuan, nilai dan sasaran; (5) Kecemasan sebagai suatu kondisi hidup; (6) Kesadaran akan datangnya maut serta ketidakberadaan, yang dimana keenam dimensi tersebut akan dikaitkan dengan konseling Islam. Di dalam Islam sendiri pun terdapat nilai - nilai yang ada pada 6 dimensi dasar positif eksistensial humanistik seperti kapasitas akan kesadaran diri yaitu mengenai fitrah dan kesadaran akan sebagai hamba Allah yang ditugaskan sebagai khalifah di Bumi, kebebasan dalam bertindak tetapi juga bertanggung jawab atas tindakannya, menciptakan hubungan yang harmonis dengan orang lain, menyadari bahwa diri memiliki keterbatasan dan harus ikhlas menghadapi kematian yang hakikatnya tidak dapat dihindari sebagai mahluk hidup dan lain - lain.
\end{abstract}

(C) 2020 The Authors. Published by UIN Sultan Syarif Kasim Riau.

This is an open access article under the CC BY license

(https://creativecommons.org/licenses/by/4.0)

\section{Corresponding Author:}

Syatria Adymas Pranajaya

Institut Agama Islam Negeri Samarinda

Email: syatria.adymas@gmail.com

\section{Pendahuluan}

Bimbingan konseling merupakan layanan yang diberikan oleh konselor kepada klien atau dalam konteks bimbingan konseling disebut sebagai konseli dengan tujuan agar konseli mampu 
menjadi pribadi yang mandiri serta mampu bertanggung jawab terhadap dirinya sendiri. Sedangkan bimbingan konseling Islam memiliki definisi yang serupa dengan bimbingan konseling akan tetapi yang membedakannya adalah pada bimbingan konseling Islam terdapat tambahan tujuan yang lain daripada sebatas menjadi pribadi yang mandiri serta mampu bertanggung jawab terhadap dirinya sendiri yaitu menjadi pribadi muslim yang taat dan patuh terhadap ajaran Islam yang berlandaskan pada Al - Qur'an dan Hadis. Dalam layanan bimbingan konseling terdapat berbagai macam teknik, salah satunya dan yang merupakan pembahasan pada artikel ini adalah teknik konseling eksistensial humanistik yang berorientasi untuk membangun kesadaran pada klien agar menjadi pribadi yang mampu menentukan pilihan sendiri serta bertanggung jawab terhadap pilihannya sendiri.

Pada dasarnya eksistensial humanistik berupaya untuk dapat memahami apa hakikat menjadi manusia serta bagaimana manusia itu mengaktualisasi dirinya. Selain itu, eksistensial humanistik menganggap bahwa setiap individu itu unik dan memiliki kehendak terhadap dirinya dan mampu menentukan nasib serta pilihan tetapi juga bertanggung jawab terhadap pilihannya. Dalam Islam, tingkah laku yang ada pada manusia tidak hanya sebatas sebagai keinginan yang bertujuan untuk mengaktualisasikan dirinya tetapi merupakan sebuah rangkaian hubungan antara manusia, alam, dan Tuhan. Kemudian, dalam Islam manusia tidak hanya berperan bagaimana menjadi manusia yang mampu mengaktualisasikan dirinya saja tetapi memiliki peran sebagai khalifah dan sebagai hamba Allah. Untuk menunjang manusia dalam menjalankan peran tersebut, maka Allah memberikan kemampuan atau potensi kepada manusia seperti kebebasan dalam bertindak, setiap manusia memiliki ciri khas atau kemampuannya masing - masing, diberi akal, hati, perasaan dan iman. Dari penjelasan tersebut (dalam Al Afify, 2018) menyimpulkan bahwa eksistensial humanistik memiliki persamaan dalam agama Islam terkhusus dalam konteks bimbingan konseling Islam.

\section{Metode}

Penelitian ini merupakan penelitian kepustakaan atau library reserch yaitu penelitian yang berfokus pada kajian sumber bacaan dan bertujuan untuk mencari persamaan, perbedaan, membandingkan ataupun menggabungkan nilai - nilai pemikirian yang terdapat pada masing - masing sumber bacaan sehingga melahirkan sebuah pemikiran yang baru dari hasil kajian tersebut. Untuk menunjang penelitian kepustakaan maka adapun pendekatan yang digunakan dalam penelitian ini yaitu pendekatan kualitatif yang sifatnya deskriptif dan metode induktif. Pendekatan kualitatif mendeskripsikan hasil penelitian yang didapat dari data - data yang diteliti, sedangkan metode induktif menjabarkan isi dari sumber bacaan kemudian merangkumnya menjadi suatu kesimpulan (Khatibah, 2011). 


\section{Hasil dan Pembahasan}

\section{A. Pokok - pokok Eksistensial Humanistik}

1. Latar belakang Eksistensialisme

Eksistensialisme pada awalnya merupakan filsafat yang menganggap bahwa segala sesuatu yang terjadi pasti berujung dari eksistensi atau kehadiran. Eksistensialisme menekankan pada ekesistensi dibandingkan dengan esensi atau hakikat. Eksistensi sendiri secara umum adalah keberadaan sedangkan secara khusus berarti bagaimana cara manusia hidup di dunia.

Maksud dari cara manusia hidup di dunia tidaklah sama dengan benda - benda yang dimana benda tidak memiliki kesadaran akan keberadaannya bahkan tidak memiliki arti. Sedangkan dengan manusia itu sendiripun mampu menyadari keberadaannya serta berarti tanpa hal yang lain. Berbeda dengan benda - benda, dengan adanya manusia barulah benda tersebut lebih berarti. Manusia bisa meragukan segala hal akan tetapi satu yang pasti yaitu manusia menyadari bahwa dirinya ada (Arawiah, 2015). Manusia diberikan potensi untuk selalu dapat berkembang dengan belajar, dalam Maulida dan Pranajaya (2018) setiap manusia dari masa anak-anak, remaja, dewasa sampai lansia sekalipun semua pasti pernah melakukan proses yang namanya belajar, bahkan pada saat masih balita sekalipun, sudah mulai belajar berbicara dan berjalan. Hal-hal tersebutlah yang melatarbelakangi eksistensi diri manusia.

Adapun yang melatar belakangi munculnya eksistensialisme yaitu pemikiran materialisme yang menganggap bahwa keberadaan manusia itu pada dasarnya sama seperti benda lain yang bersifat material. Kemudian idealisme yang menganggap bahwa manusia berpikir secara berlebihan dan memandang manusia hanya sebagai subjek. Lalu keadaan dan situasi dunia terkhusus di Eropa yang sedang tidak stabil dimana perang merupakan hal yang senantiasa ditemui sehingga menyebarkan ketakutan pada siapa saja, agama di Eropa dianggap gagal dalam memberikan makna dalam hidup, kebencian, krisis dan kacau. Sehingga manusia menganggap bahwa ulah manusia mengancam keberadaan mereka sendiri. Maka pada keadaan seperti itu, para filosof melihat pada diri mereka sendiri dan hanya berharap pada diri mereka sendiri sehingga manusia menjadi objek sekaligus subjek (Arawiah, 2015).

2. Pokok - Pokok Konseling Humanistik

Pada mulanya aliran humanistik merupakan salah satu aliran pada psikologi dimana pembahasan utama dari aliran ini adalah mengenai kesadaran diri yang harus di eksplorasi dengan introspeksi diri. Aliran ini berakar dari kalangan eksistensialisme. Pemikiran eksistensialisme sendiri berkembang pesat pada abad pertengahan. Para ahli psikologi seperti Abraham Maslow yang merupakan pelopor aliran psikologi humanistik yang menganggap bahwa manusia akan berupaya untuk dapat memahami serta menerima dirinya. Kemudian 
Carl Rogers yang merupakan psikolog humanistik, dalam proses konseling ia menekankan sikap untuk saling menghormati dan saling percaya antara konseli dengan terapis atau konselor (Arbayah, 2013) yang mampu membangun sebuah asosiasi profesional yang bertujuan untuk meneliti secara khusus mengenai keunikan - keunikan yang terdapat pada manusia. Konseling humanistik memiliki tujuan utama yaitu membantu konseli dalam mendapatkan kebebasan untuk menentukan pilihan hidup serta bertanggung jawab terhadap keputusannya (Adhi, 2017). Humanisme sendiri merupakan suatu paham yang bertujuan untuk meningkatkan derajat manusia sebagaimana manusia yang harus diakui keberadaannya (Multazam, 2015).

Konseling humanistik lebih berfokus pada kondisi manusia dan ditekankan pada pemahaman manusia itu sendiri. Humanistik menganggap bahwa manusia itu adalah mahluk yang memiliki kesadaran dan kuasa penuh atas dirinya serta mandiri untuk menentukan arah dan keinginannya sendiri. Pada konseling humanistik ini, konselor ditekankan untuk mampu menemukan potensi keunikan pada konseli. Hal ini bertujuan untuk memfasilitasi konseli dalam rangka memahami dirinya sendiri. Maka yang menjadi pengambil keputusan adalah konseli dan sebagai konselor semestinya menghormati pilihan yang diambil oleh konseli karena merupakan tanggung jawabnya sendiri. Maka konselor disini bertugas untuk membimbing konseli untuk menemukan serta menyadari potensi - potensi yang dimiliki konseli (Zulkifar dkk, 2017).

Hubungan antara konselor dan konseli merupakan hal yang sangat diutamakan dalam konseling humanistik. Faktor yang memengaruhi terjadinya perubahan - perubahan positif adalah dari kualitas hubungan tersebut. Proses dalam konseling humanistik tidak hanya sebatas pada teknik saja, akan tetapi setiap terjadinya interaksi antara konselor dan konseli itu juga merupakan proses yang mampu memengaruhi terjadinya perubahan - perubahan ke arah positif. Maka dengan hal ini, konseling humanistik juga menekankan subjektifitas dari konseli (Zulkifar dkk, 2017).

Konseling eksistensial humanistik sangat tepat digunakan dalam rangka pengembangan kepercayaan diri serta mencari jati diri dari seorang konseli. Konseling ini tidak serta merta memberi layanan untuk menyelesaikan permasalahan konseli secara langsung, akan tetapi konseling ini memberikan pelayanan untuk menyelesaikan permasalahan konseli melalui konseli itu sendiri. Maksudnya adalah konseling ini menyadarkan konseli terhadap semua tindakannya dan juga meningkatkan kemampuan pada konseli itu sendiri dengan upaya - upaya membantu konseli untuk lebih mengenal dirinya serta menemukan dimana letak kemampuan konseli itu sendiri. Pendekatan pada konseling ini tidaklah tunggal akan tetapi juga melingkupi pendekatan - pendekatan terapi lain yang juga berdasarkan pada asumsi kesadaran manusia. Adapun konsep utama dari pendekatan 
eksistensial humanistik yang dikemukakan oleh Corey, yaitu: (1) kesadaran diri, yang dimana manusia memiliki kemampuan untuk menyadari dirinya sendiri. Semakin kuat kesadaran pada diri seseorang maka semakin besar juga kebebasan pada dirinya untuk menentukan dan memutuskan sesuatu yang disertai dengan tanggung jawab; (2) Kebebasan, tanggung jawab, serta kecemasan. Kebebasan yang disertai tanggung jawab maka akan menyebabkan kecemasan pada seseorang dalam bertindak, selain itu kecemasan juga disebabkan karena kesadaran terhadap keterbatasannya diri terhadap sesuatu yang tidak dapat dihindari seperti kematian; (3) Penciptaan makna. Manusia berupaya untuk menemukan tujuan hidup serta menciptakan nilai - nilai yang mampu memengaruhi makna dalam kehidupan (Yulianti, 2019).

Begitupun pada teknik konseling humanistik yang tidak ditentukan secara ketat. Akan tetapi teknik pada konseling humanistik memiliki beberapa prinsip, yaitu: (1) membina hubungan yang baik, tujuannya agar proses konseling bisa berjalan lancar karena dengan hubungan yang baik antara konselor dan konseli akan menciptakan keterbukaan dan mau berinteraksi dengan konselor; (2) membuat klien mampu menerima dirinya dengan segala potensi dan keterbatasan yang dimiliki, hal ini sesuai dengan tujuan dari konseling humanistik agar konseli mampu menyadari dan menerima kekuatan - kekuatan yang dimiliki oleh konseli serta keterbatasan - keterbatasan yang ada pada dirinya sehingga perkembangan konseli bisa berjalan secara optimal; (3) merangsang kepekaan emosi klien, yaitu kepekaan emosi yang akan memicu kesadaran terhadap diri konseli; (4) membuat klien bisa mencari solusi permasalahannya sendiri, tujuannya adalah untuk membentuk pribadi konseli yang mandiri sebab eksistensial menganggap bahwa individu lah yang memiliki kebebasan dalam menentukan serta bertanggung jawab atas pilihan itu; (5) mengembangkan potensi dan emosi positif klien, hal ini sejalan dengan tujuan konseling eksistensial humanistik yaitu membantu konseli menyadari atas potensi yang dimiliki kemudian membantu untuk mengembangkannya yang tentunya tergantung dari pilihan konseli sendiri (Khoirina, 2018).

Teknik - teknik yang digunakan dalam konseling eksistensial humanistik cenderung untuk membangkitkan kesadaran dan potensi - potensi yang ada pada diri konseli dibandingkan untuk memengaruhi atau dalam konteks ini adalah mengubah dengan cara menggantikan, tetapi teknik konseling humanistik murni untuk memancing keluar potensi yang terdapat pada konseli sehingga dengan begitu konseli bisa merubah dirinya sendiri. Untuk dapat membangkitkan kesadaran dan potensi pada diri konseli, maka konselor memusatkan perhatian pada keunikan konseli seperti sifat, daya analisis, kemampuan khusus, kreatifitas dan imajinasi. Hal ini sesuai dengan pandangan eksistensialisme mengenai manusia bahwa manusia itu unik atau memiliki ciri khasnya masing - masing yang bisa mereka kembangkan sendiri (Hasna, 2019). 
Menurut Gerald Corey, tujuan dari terapi eksistensial adalah membuat konseli memiliki kesadaran yang utuh terhadap dirinya yang berarti menyadari kekuatan serta potensi - potensi maupun keunikan yang terdapat dalam dirinya dan melakukan sesuatu sesuai kemampuan dirinya. Selain membuat konseli sadar terhadap dirinya, tujuan selanjutnya adalah untuk memperluas kesadaran itu sehingga meningkatkan pilihan dan bertanggung jawab atas pilihan dalam kehidupannya. Lalu membantu konseli dalam mengatasi kecemasan dengan menyadarkan untuk menerima kenyataan - kenyataan di luar dari kehendak dirinya (Nurwan, 2019).

Dalam Eksistensial humanistik terdapat enam dimensi dasar positif yang ada pada manusia, yaitu: (1) Kapasitas akan kesadaran diri; (2) Kebebasan serta tanggung jawab; (3) Menciptakan identitas dirinya dan menciptakan hubungan yang bermakna dengan orang lain; (4) Usaha pencarian makna, tujuan, nilai dan sasaran; (5) Kecemasan sebagai suatu kondisi hidup; (6) Kesadaran akan datangnya maut serta ketidakberadaan, yang dimana keenam dimensi tersebut dapat dikaitkan dengan konseling Islam (Anwar, 2011).

\section{B. Pokok - Pokok Bimbingan Konseling Islam}

1. Definisi Bimbingan Konseling Islam

Bimbingan dan konseling memiliki definisi yang berbeda. Bimbingan merupakan terjemahan dari kata bahasa Inggris yaitu guidance yang dimana di dalam kata tersebut terdapat beberapa makna, menurut Sertzer dan Stone makna tersebut ialah menunjukkan, mengarahkan, menentukan, mengatur, atau mengemudikan. Sedangkan konseling merupakan terjemahan dari kata counceling yang bermakna nasihat, anjuran, dan pembicaraan. Maka dapat dipahami bahwa bimbingan dan konseling tidak dapat dipisahkan meskipun memiliki makna yang berbeda sebab merupakan aktivitas yang saling berkaitan dan terangkai sebagai suatu kesatuan yang utuh. Sedangkan bimbingan konseling Islam merupakan upaya permberian layanan untuk membantu individu dalam kehidupan keagamaannya sesuai dengan syarat serta kewajiban yang telah Allah berikan, untuk mencapai kehidupan yang bahagia baik di dunia maupun di akhirat. Sebenarnya bimbingan agama telah dilakukan sejak zaman dulu bahkan zaman nabi (Prasetya, 2014).

\section{Fungsi Bimbingan Konseling Islam}

Bimbingan konseling Islam memiliki dua fungsi utama yaitu fungsi secara umum dan fungsi untuk berdakwah. Fungsi secara umum yaitu berupaya untuk membantu konseli untuk mengatasi hambatan - hambatan yang terjadi dalam proses perkembangan dan pertumbuhan agar berjalan dengan lancar. Sedangkan fungsi untuk berdawah adalah bimbingan konseling 
Islam memberikan bantuan kepada individu maupun kelompok yang sedang mengalami kesulitan atau masalah dalam menjalani kehidupannya menggunakan pendekatan agama Islam dengan membangkitkan kekuatan iman agar mampu menyelesaikan permasalahannya. Maka dari itu, bimbingan konseling Islam merupakan bantuan yang bersifat mental spiritual. Dengan membangkitkan kekuatan iman, hal ini tentunya mengarah kepada dakwah untuk mengajak menjalin hubungan yang kuat dengan Allah (Prasetya, 2014).

3. Metode Bimbingan Konseling Islam

a. Metode penyesuaian. Metode ini lebih berfokus pada perbedaan antar individu dibandingkan dengan persamaannya. Sebab, tiap individu menghadapi masalah yang berbeda antar individu lainnya termasuk kebutuhannya sehingga layanan yang diberikanpun tentunya berbeda. Maka konselor diharuskan mampu menyesuaikan metode dengan ciri khas dari konseli.

b. Metode dinamis. Berlandaskan pada konsep manusia itu dinamis dan selalu mengalami perubahan. Metode ini bertujuan untuk membantu konseli dalam melakukan perubahan kearah yang lebih baik. Sehingga konselor dituntut untuk lebih memperhatikan pada perubahan - perubahan yang terjadi pada konseli (Alwi, 2018).

\section{Pandangan Eksistensialisme Humanistik Mengenai Unsur - Unsur Dalam Konseling}

1. Hakikat Manusia

Eksistensialisme memandang bahwa manusia pada dasarnya bersifat baik dan dinamis atau selalu bergerak untuk melakukan perubahan - perubahan pada dirinya yang memiliki kecenderungan kearah yang positif. Sebab, manusia memiliki akal yang mampu membedakan hal - hal mana yang baik dan yang buruk serta memiliki hak kendali atas dirinya. Dari penjelasan tersebut maka eksistensialisme memiliki pandangan yang positif terhadap sifat dasar manusia (Anwar, 2011), yang dimana hal ini memiliki keterlibatan yang kuat dengan terapi yang lebih berfokus pada kapasitas klien mengenai kemampuannya untuk menyadari potensi - potensi serta kemampuan yang dimiliki.

2. Pribadi Sehat

Dalam pandangan eksistensialisme menganggap bahwa apabila seseorang mampu menjalankan keenam fungsi dimensi dengan benar maka orang itu dikatakan memiliki pribadi yang sehat. Beberapa ciri - ciri seseorang memiliki pribadi yang sehat yaitu seperti berpikir positif, dapat dipercaya, kreatif, dan mampu memahami diri sendiri yang dimana dari beberapa ciri tersebut disebabkan karena ia mampu menjalankan keenam fungsi dimensi 
dengan benar (Anwar, 2011). Diperlukan juga kemampuan, pengetahuan dan kepatuhan dari individu dalam mengelola perilakunya dikehidupan sehari-hari (Nina dan Pranajaya, 2020) sehingga keenam fungsi dimensi tersebut dapat dikontrol dengan baik.

3. Pribadi Tak Sehat

Berbanding terbalik dengan pribadi sehat, seseorang dikatakan memiliki pribadi yang tak sehat apabila ia tidak mampu menjalankan keenam fungsi dimensi dengan benar. Sehingga, pada dirinya tercipta sifat - sifat negatif seperti tidak mampu memahami diri sendiri, tidak produktif, tidak dapat dipercaya (Anwar, 2011), serta tidak dapat mengontrol diri sendiri keranah pribadi yang sehat secara jasmani maupun rohani.

4. Tujuan Konseling

Tujuan konseling eksistensial humanistik adalah untuk membantu klien agar memiliki kesadaran secara penuh terhadap potensi - potensi pada dirinya. Lalu, menyadarkan klien terhadap tanggung jawab yang disebabkan oleh keputusannya. Kemudian, mengidentifikasi hambatan - hambatan yang dialami oleh klien dalam rangka pengembangan dirinya. Konseling ini lebih tertuju kepada pribadi klien dibandingkan dengan pokok permasalahan yang dikemukakan oleh klien, maksudnya adalah konseling lebih kepada memperbaiki fungsi pribadi klien agar klien mampu menangani masalahnya secara mandiri dibanding fokus kepada menyelesaikan masalah - masalah yang dikemukakan oleh klien itu sendiri.

\section{Hubungan Terapis dengan Klien}

Terapis bertugas untuk menghadirkan kesadaran klien secara utuh dan mengadakan pertemuan secara face to face. Dari hubungan ini maka klien mampu menemukan keunikan yang terdapat pada dirinya dalam hubungan tersebut. Selain itu, Terapis dan klien saling mempengaruhi (Anwar, 2011). Namun hubungan pengaruh dan mempengaruhi tidak selamanya positif bagi terapis (dalam hal ini konselor), karena pada proses konseling, seorang konselor akan menghadapi berbagai macam persoalan-persoalan, emosi dan pengalaman negatif dari kliennya. Situasi seperti ini akan menyebabkan konselor rentan dalam mengalami trauma sekunder yaitu suatu trauma yang dialami oleh konselor meski ia tidak menghadapi kejadian traumatisnya secara langsung (dalam Nina dan Pranajaya, 2020), sehingga konselor sudah seharus memiliki teknik dan prosedur tertentu dalam proses konseling.

6. Teknik dan Prosedur

Dalam ekesitensial ini tidak memiliki perangkat teknik yang siap pakai. Maka dari itu, terapis eksistensial menggunakan teknik pendekatan lain, pada awalnya lebih ditekankan pada 
pemahaman setelah itu baru menggunakan teknik. Terapi ini memusatkan pada penggunaan pribadi terapis. Selain itu, (dalam Anwar, 2011) terdapat 3 tahapan konseling ini yaitu pertama tahap awal, kemudian tahap pertengahan, lalu tahap akhir.

7. Fungsi dan Peran Konselor

Konselor terlebih dahulu harus memahami sudut pandang dari klien atau berperan sebagai seseorang yang memahami pribadi klien dari perspektif klien itu sendiri yang berfungsi sebagai pemberi bantuan untuk menentukan alternatif serta membantu klien memahami dirinya sendiri (Anwar, 2011).

\section{Dimensi Dasar Positif Eksistensial Humanistik Dalam Perspektif Islam}

Dalam Islam terdapat banyak pembahasan mengenai dimensi - dimensi kehidupan manusia, termasuk dimensi - dimensi yang ada pada eksistensial humanistik.

1. Kapasitas akan Kesadaran Diri

Ruang lingkup kesadaran diri pada Islam meliputi fitrah manusia dan penerima pembenaran (terdapat pada Surah Ar - Rum ayat 30), perjanjian mengakui Allah sebagai Tuhan (terdapat pada Surah Al - A'raf ayat 172), manusia memiliki potensi akal, pendengaran, penglihatan dan hati (terdapat pada Surah Ar - Ra'd ayat 19-20), manusia dibekali dengan petunjuk ilahiyah (Surah Al - Fatihah ayat 7), manusia sebagai khilafah (Surah Al - Baqarah ayat 30), manusia diberi amanat (Surah Al - Ahzab ayat 72), dan manusia mengabdi kepada Allah (Surah Adz - Dzariyat ayat 56). Ketika manusia lahir ke dunia maka ia dalam keadaan fitrah yaitu memiliki naluri untuk beragama Tauhid. Maka dari kapasitas kesadaran diri dalam Islam adalah kesadaran manusia mengenai keberadannya sebagai hamba Allah yang senantiasa mengabdi kepada-Nya serta melaksanakan tugas - tugas sebagai khilafah serta mampu menggunakan potensi - potensi yang dimilikinya berupa akal dan berbagai indra untuk memahami tanda - tanda kekuasaan Allah. Selain itu, dalam Islam yang menjadi pusat segalanya adalah Allah sebagai pencipta manusia meskipun manusia hanya sebagai pusat hubungan - hubungan, hanya saja berbeda dengan aliran eksistensial yang menjadi pusatnya adalah manusia (Anwar, 2011)

2. Kebebasan dan Bertanggungjawab

Terdapat beberapa ayat dalam Al - Qur'an yang menjelaskan bahwa manusia memiliki kebebasan untuk berkehandak serta bertanggung jawab atas perbuatan yang dilakukan. Manusia memiliki kebebasan dalam bertindak (Surah Asy - Syam ayat 8) dan bertanggung jawab terhadap apa yang telah dilakukan (Surah Al - Qiyamah ayat 13 -15). Serupa dengan eksistensial bahwa manusia memiliki kehendak dalam menentukan tindakan 
atau keputusannya, dalam Islam juga terdapat konsep kebebasan dalam berkehendak yang diberikan oleh Allah kepada manusia serta konsep bertanggung jawab terhadap perbuatan manusia sendiri. Hal ini serupa dengan dimensi positif eksistensialisme yang menganggap individu memiliki kebebasan akan tetapi harus bertanggung jawab terhadap keputusan dan tindakan yang dilakukannya (Hidayatulloh, 2012).

3. Menciptakan Identitas Dirinya dan Menciptakan Hubungan yang Bermakna dengan Orang Lain

Terdapat 4 hubungan antar manusia yang terdiri dari sisi positif dan negatif, yaitu:

a. Kesadaran manusia terhadap dirinya sendiri dengan melakukan amal ma'ruf nahi munkar (Surah Ali Imran ayat 110) atau mengumbarkan nafsunya (Surah Yasin ayat 6). Manusia bisa memilih hubungan terhadap dirinya dan membentuk identitas diri dengan melakukan amal ma'ruf nahi munkar yang dimana jika seseorang memilih ini tentunya akan membangun identitas dan hubungan dengan diri sendiri menjadi positif, berbanding terbalik jika manusia memilih untuk mengumbar nafsunya maka akan menciptakan identitas serta hubungan dengan diri sendiri menjadi negatif.

b. Hubungan manusia dengan manusia yang lain, bisa dilakukan dengan membangun silaturahmi (Surah An - Nisa ayat 1) atau memutuskan hubungan itu (Surah Yusuf ayat 100). Manusia bisa memilih bagaiaman hubungannya dengan manusia yang lain. Jika ia memilih untuk membangun silaturahmi yang baik maka identitas dirinya serta hubungan dengan manusia yang lain akan menjadi positif, sebaliknya jika ia memilih untuk memutuskan silaturahmi dengan manusia yang lain maka akan menciptakan identitas serta hubungan yang tidak baik dengan manusia yang lain.

c. Hubungan manusia dengan alam, dengan merawat serta melestarikan alam(Surah Hud ayat 6) atau merusak alam (Surah Ar-Rum ayat 41). Manusia bisa memilih untuk merawat serta melestarikan alam sehingga tercipta identitas yang positif dan hubungan yang positif dengan alam atau memilih untuk merusak alam sehingga tercipta identitas manusia yang negatif dan memiliki hubungan yang buruk dengan alam.

d. Hubungan manusia dengan Tuhan, dengan mematuhi perintah dan kewajiban beribadah kepada-Nya (Surah Adz - Dzariyat 56) atau tidak menaati dan syirik kepada-Nya (Surah An - Nisa ayat 48). Manusia bisa memilih untuk taat dan patuh beribadah kepada Sang Pencipta untuk menciptakan identitas dan hubungan yang baik atau memilih untuk ingkar, membangkang dan syirik sehingga tercipta identitas dan hubungan yang tidak baik dengan Sang Pencipta. Maka Islam memandang serupa dengan eksistensial bahwa manusia mampu menentukan pilihan serta tindakannya baik itu berdampak positif ataupun negatif (Anwar, 2011). 
4. Usaha Pencarian Makna, Tujuan, Nilai, dan Sasaran

Islam memandang bahwa manusia diberi kemampuan batin dan keyakinan yang teguh (Surah Al - Anfal ayat 2-4) sehingga senantiasa optimis, diberi kelebihan dibandingkan dengan mahluk lain (Surah Al - Isra ayat 70) dan berbagai indra serta hati dan akal agar mampu bersyukur (Surah An - Nahl ayat 78). Dari semua itu, maka manusia mampu mengambil hikmah dari peristiwa yang terjadi di sekelilingnya meskipun tantangan yang dihadapi khazanah Islam dengan sifat klasiknya terhadap perubahan modernisasi dan pengaruh globalisasinya semakin membiaskan pencarian makna, tujuan, nilai dan sasaran manusia dalam kehidupan, namun dengan potensi-potensi yang diberikan Sang Pencipta tersebut, maka manusia memiliki fitrah yang mampu menemukan keyakinan bahwa Allah yang memberikan ujian-ujian kepada hamba-Nya dengan berbagai macam keadaan. Hal ini menunjukkan bahwa manusia hendaknya mampu menemukan makna, tujuan, nilai serta sasaran dari peristiwa - peristiwa yang terjadi di sekelilingnya ataupun yang menimpa dirinya (Anwar, 2011).

5. Kecemasan sebagai Suatu Kondisi Hidup

Terdapat berbagai tingkat pada kecemasan yang dirasakan oleh manusia. Baik itu mulai dari tingkat tinggi hingga tingkat rendah. Kehampaan atau kekosongan berawal dari kecemasan yang dialami oleh seseorang diakibatkan ia tidak mampu menemukan makna hidup sehingga menganggap hidupnya tidak memiliki arti. Islam memandang kehampaan ini karena tidak mengingat Allah sebagai Tuhannya, maka solusi yang ditawarkan adalah dzikrullah atau mengingat Allah. Dengan mengingat Allah Sang Pencipta, dan Yang Maha Kuasa atas segala sesuatu akan memberikan ketenangan yang mengisi kekosongan yang ada. Dalam Al - Qur'an dijelaskan bahwa Allah tidak akan memberikan ujian melewati batas kemampuan hamba-Nya, selain itu Islam mengemukakan bahwa dengan berserah diri kepada Allah maka hati akan terasa lebih tenang sehingga dengan begitu mampu meredam kecemasan - kecemasan yang ada pada kehidupan (Surah Al - Mu'minun ayat 62).

6. Kesadaran akan Datangnya Maut Serta Ketidakberadaan

Dalam Al - Qur'an mengemukakan bahwa setiap yang bernyawa pasti akan mati (Surah Ali Imran ayat 185). Kematian merupakan salah satu misteri yang tidak diketahui kapan datangnya. Tetapi Islam mengharuskan pengikutnya untuk memercayai bahwa kematian itu ada dan pasti datang. Maka dari itu, manusia hendaknya menyadari eksistensinya di dunia ini, untuk apa ia hidup dan bagaimana setelah mengalami kematian. 
Islam mengemukakan bahwa kehidupan ini adalah untuk beribadah dan mengabdi kepada Allah (Anwar, 2011).

\section{E. Penerapan Dimensi Dasar Positif Eksistensial Humanistik Dalam Unsur - Unsur Konseling Dengan Perspektif Bimbingan Konseling Islam}

Penerapan konseling Islam pasti mengacu pada unsur - unsur konseling umum. Dimana dalam konseling Islam terdapat nilai - nilai yang serupa dengan konseling umum. Sehingga, konseling umum tidak bisa dilepaskan dengan konseling Islam. Hanya saja, bimbingan konseling Islam lebih berlandaskan pada nilai - nilai keislaman sehingga penerapan dimensi dasar positif eksistensial humanistik kedalam unsur - unsur konseling berdasarkan dengan nilai - nilai keislaman.

1. Mengenai hakikat manusia.

Dalam Islam, manusia itu bersifat netral dan yang menentukan aktif atau pasif adalah rentang waktu. Suatu waktu bisa bersifat pasif dan pada keadaan di waktu lain bersifat aktif. Sebagai contoh pada masa balita, manusia bersifat pasif sebab potensi - potensi yang dimiliki belum berfungsi secara optimal dan yang bertanggung jawab atas perbuatan tersebut adalah orang tuanya. Kemudian pada masa setelah akil balig, manusia bersifat aktif sebab potensi yang dimilikinya sudah berfungsi secara optimal, dan bertanggung jawab atas perilaku dan keputusan dirinya sendiri. Manusia secara fitrah memiliki naluri untuk beragama tauhid dan terikat bahwa Allah adalah Tuhannya, selian itu manusia memiliki kebebasan untuk bertindak serta dilengkapi dengan beragam macam indra, akal, hati, dan juga petunjuk ilahiyah agar mampu menjalankan tugas - tugas sebagai khalifah yang taat kepada Allah (Anwar, 2011).

2. Mengenai pribadi sehat.

Dalam Islam, pribadi sehat adalah ketika iman mampu menentukan dalam hal kognitif, afektif, serta psikomotorik yang berarti tindakan dan perbuatan seseorang sesuai dengan fitrah yang mengarah kepada kebahagiaan dalam kehidupan di dunia maupun di akhirat. Selain itu, dengan berfungsinya iman sebagai penentu tindakan dan perbuatan hal itu juga akan membentuk mental yang sehat. Dengan mental yang sehat maka seseorang akan lebih mudah dan senantiasa optimis dalam menjalankan kehidupan sehari - harinya (Anwar, 2011). Cara berpikir selektif dalam mengikuti arus modernisasi sesuai dengan kebutuhan perkembangan yang bernilai manfaat dan efektif serta tetap memperhatikan dampak baik buruknya dalam kehidupan. Berbeda di lingkungan masyarakat yang masih labil cara berfikirnya, sehingga akan mengadopsi segala hal yang baru untuk dapat disebut sebagai modern. Akibatnya kehidupan hanya bersifat simbolis tanpa mempertimbangkan sisi fungsionalnya dalam berkehidupan (Hafidzi, 2019).

3. Mengenai pribadi tak sehat. 
Berbanding terbalik dengan pribadi sehat, pribadi tak sehat adalah ketika iman tidak mampu menjadi penentu dalam hal kognitif, afektif, dan psikomotorik. Seperti berbuat kerusakan, syirik, serta tidak menggunakan akalnya.

4. Mengenai tujuan konseling.

Tujuan konseling dalam bimbingan konseling Islam adalah untuk memberdayakan iman. Seperti mengakui bahwa Allah adalah Tuhannya, Allah membekali ia dengan beragam potensi seperti akal, hati, dan berbagai indra untuk menunjang dalam menjalankan kehidupan yang terdapat berbagai macam ujian serta melaksanakan berbagai tugas - tugas sebagai khalifah di Bumi.

5. Mengenai hubungan terapis dengan klien.

Hubungan antara terapis dan klien dalam bimbingan konseling Islam merupakan hubungan teladan yang baik. Maksudnya adalah konselor menjadi teladan yang baik bagi konselinya. Dalam hal ini maka konselor hendaknya memahami diri sendiri terlebih dahulu kemudian setelah itu baru dapat memahami konseli, agar tidak terjadi kesalah pahaman terhadap permasalahan konseli.

6. Mengenai Teknik dan metode.

Dalam bimbingan konseling Islam menggunakan teknik sama halnya dengan cara dakwah Rasulullah. Yaitu dengan hikmah, hikmah sendiri berarti mengetahui yang benar. Apabila konteksnya dakwah maka terlebih dahulu mengetahui tujuan serta mengenal dengan benar mengenai masyarakat atau sasaran dakwah, begitupula dengan konselor hendaknya mampu mengenali konseli dengan benar. Lalu dengan pengajaran dan nasihat, apabila konteksnya adalah dakwah maka berdakwah dengan cara pengajaran serta nasihat yang disukai oleh sasaran dakwah serta penuh dengan kelembutan, begitu pula dengan konselor yang harus bersikap baik dan hangat terhadap konseli sehingga menciptakan rasa nyaman yang membuat konseli terbuka kepada konselor. Kemudian dengan berbantah dan berdebat dengan cara yang baik, apabila konteksnya dakwah maka dengan bertukar pikiran antara pendakwah dan sasaran dakwah dengan tujuan untuk mengajak sasaran dakwah kepada keimanan terhadap Allah. Sedangkan jika konteksnya konseling maka konselor mampu bertukar pikiran dengan konseli dalam rangka untuk lebih memahami kondisi serta sudut pandang konseli, terlebih dalam konseling humanistik konselor ditekankan pada subjektivitas konseli (Prasetya, 2014)

7. Mengenai peran dan fungsi konselor. 
Dalam bimbingan konseling Islam, konselor bisa berperan sebagai guru, teman, orang tua bahkan model. Maka dari itu konselor Muslim selain menguasai teknik - teknik dalam bimbingan konseling secara umum juga harus memiliki kapasitas dan memahami agama Islam. Sehingga mampu mencapai tujuan konseling Islam yaitu memberdayakan iman pada konseli (Anwar, 2011).

\section{Kesimpulan}

Pada eksistensial humanistik menganggap bahwa manusia itu unik dan memiliki potensinya masing - masing yang dapat mereka kembangkan sendiri dan juga pada dasarnya cenderung bersifat positif serta dinamis atau selalu bergerak mengalami perubahan yang mengarah kepada kebaikan, selain itu eksistensial humanistik memandang bahwa individu lah yang memiliki otoritas terhadap dirinya seperti menentukan tindakan bahkan juga nasibnya. Sedangkan Islam memandang bahwa manusia pada dasarnya memiliki kecenderungan untuk beragama Tauhid yaitu mengakui bahwa dirinya sebagai hamba Allah yang ditugaskan sebagai khalifah di Bumi dengan potensi - potensi yang diberikan oleh Allah kepada dirinya seperti iman, akal, perasaan, dan berbagai alat indera serta diberi kebebasan dalam berkehendak yang tentunya juga harus bertanggung jawab atas perbuatan yang dilakukan. Dari penjelasan diatas maka penulis menyimpulkan bahwa bimbingan konseling Islam memandang eksistensial humanistik merupakan teori yang paling mendekati dengan nilai - nilai Islam, yaitu seperti memandang bahwa manusia cenderung mengarah kepada pribadi yang baik, memiliki potensi - potensi atau bakat, dan memiliki kebebasan dalam bertindak tetapi harus bertanggung jawab terhadap tindakannya. Akan tetapi yang membedakannya adalah bahwa eksistensial humanistik memandang manusia secara mutlak bahwa yang menentukan dirinya hanyalah dirinya seorang dan tidak ada campur tangan dari pihak lain sehingga menganggap bahwa individu adalah Tuhan bagi dirinya sendiri karena yang mampu menentukan dirinya hanyalah dirinya seorang, sedangkan dalam Islam selain yang menentukan adalah dari individu itu sendiri terdapat campur tangan dari pihak lain yang menentukan yaitu Allah yang berkehendak atas segala sesuatu. Jadi terdapat kesamaan dan perbedaan antara eksistensial humanistik dengan Islam. Meskipun begitu, ekesistensial humanistik dapat diterapkan dalam bimbingan konseling Islam sebab eksistensi humanistiklah yang lebih mendekati Islam, tetapi dalam proses bimbingan konseling Islam yang menggunakan eksistensial humanistik tentunya juga menggunakan nilai - nilai keislaman seperti adanya campur tangan Allah dalam menentukan tindakan dan nasib dari individu.

\section{Referensi}

Adhi, N. K. J. (2017). Efektivitas Konseling Eksistensial Humanistik Dengan Kebermaknaan Hidup Pada Tunanetra. Jurnal Psikologi Mandala, Vol. 1 (No. 1), 44. 
Al Afify, M. F. (2018). Konsep Fitrah Dalam Psikologi Islam. Jurnal TSAQAFAH, Vol. 14 (No. 2), 293.

Alwi, S. (2018). Pendekatan Dan Metode Konseling Islami. Jurnal ITQAN, Vol. 9 (No. 2), 153.

Anwar, M. F. (2011). Terapi Eksistensial Humanistik Dalam Konseling Islam. Jurnal Holistik, Vol. 12 (No. 1), 157-175.

Arawiah, R. (2015). Aliran Eksistensialisme Dalam Pandangan Filsafat Pendidikan Islam. Jurnal AL - BANJARI, Vol. 14 (No. 1), 2-4.

Arbayah. (2013). Model Pembelajaran Humanistik. Jurnal Dinamika Ilmu, Vol. 13 (No. 2), 206 - 207.

Hafidzi, A. (2019). Konsep Toleransi Dan Kematangan Agama Dalam Konflik Beragama Di Masyarakat Indonesia. Potret Pemikiran, 23 (2), 51-61.

Hasna, A. (2019). Konseling Kelompok Dengan Pendekatan Eksistensial Humanistik Untuk Melatih Penyesuaian Diri Melalui Randai Dari Minangkabau. Jurnal Ilmiah POLYGLOT, Vol. 15 (No. 1), $128-129$.

Hidayatulloh, Z. (2012). Islam Dan Humanisme Menurut Seyyed Hossen Nasr. IAIN Sumatera Utara Medan.

Khatibah. (2011). Penelitian Kepustakaan. Jurnal Iqra', Vol. 05 (No. 01), 37.

Khoirina, N. (2018). Pentingnya Pemahaman Nilai - Nilai Budaya Lokal Dalam Pendekatan Konseling Humanistik. Prosding NSBK 2 (1), 266.

Maulida, N. C., \& Pranajaya, S. A. (2018). Pengentasan degradasi minat belajar pada siswa remaja. Tarbiyah Wa Ta'lim: Jurnal Penelitian Pendidikan dan Pembelajaran, Vol. 5 (No. 1), 7-16. https://doi.org/10.21093/twt.v5i1.2421

Multazam, A. (2015). Pendidikan Islam Berbasis Humanisme Religius (Studi Pemikiran Abdurrahman Mas'ud). UIN Walisongo Semarang.

Nina, \& Pranajaya, S. A. (2020). Konsep Self-Care Bagi Konselor di Masa Pandemi. Taujihat: Jurnal Bimbingan Konseling Islam, Vol. 1 (No. 1), 33-45. https://journal.iainsamarinda.ac.id/index.php/TAUJIHAT/article/view/2458

Nurwan, D. (2019). Layanan Konseling Dengan Pendekatan Eksistensial Humanistik Dalam Penyesuaian Diri Remaja. UIN Sultan Maulana Hasanuddin Banten.

Prasetya, A. M. (2014). Kolerasi Antara Bimbingan Konseling Islam Dan Dakwah. Jurnal ADDIN, Vol. 8(No. 2), $413-418$.

Yulianti, A. dan Y. K. (2019). Implementasi Eksistensial Humanistik Dengan Teknik Modeling Untuk Meningkatkan Empati Pada Mahasiswa. Jurnal Al-Fath: Pendidikan Dan Keislaman, Vol. 2 (No. 2), 251.

Zulkifar dkk. (2017). Konseling Humanistik: Sebuah Tinjauan Filosofi. Jurnal Konseling GUSJIGANG, Vol. 3 (No. 1), 147-149. 